
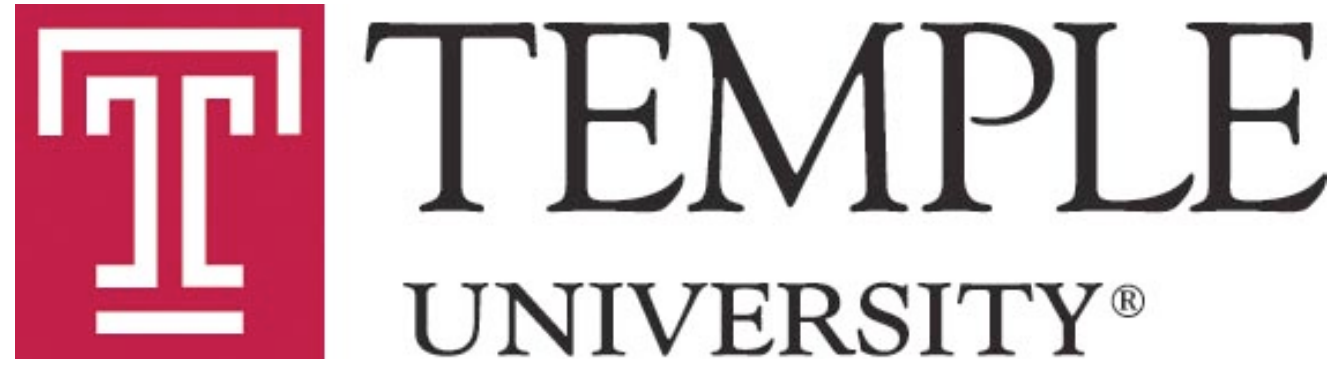

\title{
Immigration and access to fringe benefits: Evidence from the Tobacco Use Supplements
}

\author{
by \\ Johanna Catherine Maclean \\ Department of Economics \\ Temple University \\ catherine.maclean@temple.edu \\ Douglas Webber \\ Department of Economics \\ Temple University \\ douglas.webber@temple.edu
}

Jody L. Sindelar

Division of Health Policy, School of Public Health

Yale University

jody.sindelar@yale.edu

Department of Economics

DETU Working Paper 15-03

January 2015

1301 Cecil B. Moore Avenue, Philadelphia, PA 19122

http://www.cla.temple.edu/economics/faculty/detu-working-paper-series/ 


\title{
Immigration and access to fringe benefits: Evidence from the Tobacco Use Supplements
}

\author{
Johanna Catherine Maclean ${ }^{1} *$ \\ Douglas Webber ${ }^{2}$ \\ Jody L. Sindelar ${ }^{3}$
}

December, 2014

We examine the extent to which assimilation and residential ethnic enclaves are associated with immigrant access to smoking-related fringe benefits. In particular, we consider access to office smoking bans and employer-sponsored smoking cessation programs. These worksite characteristics are important and understudied fringe benefits. They are critical because they can protect immigrants from exposure to environmental tobacco smoke in the workplace and can help immigrant smokers quit smoking. We first document that immigrants have lower access to these benefits than natives. Second, we show that assimilation is positively associated with smoking-related fringe benefit access while enclave residence does not predict access.

*Corresponding author

Keywords: Smoking, fringe benefits, immigrants, assimilation, ethnic enclaves.

JEL classification: I1; JI

${ }^{1}$ Associate Professor, Department of Economics, Temple University, E-mail: catherine.maclean@temple.edu.

${ }^{2}$ Assistant Professor, Department of Economics, Temple University, E-mail: douglaswebber@temple.edu.

${ }^{3}$ Professor, Division of Health Policy, School of Public Health, Yale University, E-mail: jody.sindelar@yale.edu.

Acknowledgements: We thank session participants at the 2013 Addiction Health Services Research Conference for helpful comments and suggestions. 


\section{Introduction}

This study examines the importance of economic assimilation and ethnic enclave residence for access to smoking-related fringe benefits, as measured by protection from exposure to environmental tobacco smoke (ETS) in the workplace and access to employer-sponsored smoking cessation programs. To this end, we use detailed smoking-related information contained in the Current Population Survey Tobacco Use Supplements (TUS) between 1995 and 2011. Thus, our study contributes to the broader literature on immigrant employment outcomes by considering important, but unstudied, forms of fringe benefits.

We chose to consider smoking-related fringe benefits because smoking imposes both large internal costs on smokers and external costs on society. For example, smoking leads to $\$ 119$ billion in healthcare costs per year (Centers for Disease Control and Prevention 2008). Smoking increases healthcare costs through increased morbidity and mortality (Centers for Disease Control and Prevention 2008), use of publicly provided health insurance (Zhang, Miller et al. 1999), and higher insurance premiums for smokers and non-smokers (Halpern, Madison et al. 2009; Pearson and Lieber 2009). The full costs of smoking may extend to the labor market through lower productivity and increased absenteeism (Centers for Disease Control and Prevention 2008; Berman, Crane et al. 2013; Sherman and Lynch 2013). Lastly, exposure to ETS may harm non-smokers' health (Institute of Medicine 2010).

Immigrants are potentially an important group to study as the U.S. immigrant population has increased substantially over time. In 2011 there were over 40 million immigrants living in the U.S., an increase from 31.1 million (23\%) in 2000 (Pew Research Center 2013). Also, the type of immigrant who chooses to migrate to the U.S. is changing. During previous migration waves (e.g., 1890 to 1920) immigrants often originated from Europe, while more modern waves 
tend to migrate from Latin American and Asia (Pew Research Center 2013), importantly these countries often have higher smoking rates than the U.S. (Leung 2013). While immigrants seem to have lower prevalence rates of smoking than the rest of their country and even than those in the U.S. (Leung 2013), a non-trivial proportion smoke (13\% of immigrants in our sample relative to $21 \%$ of natives). Because immigrants tend to work in lower wage jobs than natives, a concern is that they may have less access to protections from ETS in the workplace and also to employersponsored smoking cessation programs. These are topics that we address in this study.

Several findings emerge from our analysis. First, we show that immigrants have lower access to smoking-related fringe benefits than natives. Second, we find that assimilation into U.S. society may allow immigrants to gain access to smoking-related fringe-benefits while ethnic enclave residence is not linked with such access. Third, although not a central objective of our study, we find only limited evidence that state government laws designed to protect individuals from ETS (as measured by worksite smoking bans) are passed on to immigrant workers.

\section{Related Literature}

In this section, we briefly review the economic literatures on assimilation and ethnic enclave residence. Each of these literatures is large and growing, and thus it is beyond the scope of this study to comprehensively discuss each. Instead, we highlight the work most relevant for our analysis and focus only on immigration to developed countries, especially to the U.S.

\subsection{Assimilation}

Economists have historically taken great interest in how immigrants assimilate, or converge towards natives, in terms of standard employment outcomes, e.g., earnings, occupation. The term assimilation suggests the extent to which an immigrant identifies with the social norms in the host country relative to the country of origin (Borjas 1995). Economists typically model 
assimilation as a linear process proxied by the number of years since immigration (Chiswick 1978; Antecol and Bedard 2006; Lubotsky 2007; Leung 2013).

The immigrant literature is tightly linked with the Roy model of worker sorting (Roy 1951). Chiswick (1978) pioneered this line of research using a Mincerian human capital framework. In this framework, the decision to immigrate is interpreted as an investment in one's human capital. Immigrants are viewed as rational decision makers who maximize their lifetime utility subject to constraints. They decide to invest in their human capital, or immigrate in this case, when the expected benefits exceed expected costs. Chiswick (1978) predicted positive selection into immigration based on work-related ability and ethic; more capable workers could extract higher benefits from immigration, and face lower costs, than others. Chiswick (1978) documented that immigrants initially experience worse employment outcomes relative to natives as their skills may not be perfectly transferable to the host country labor market, but eventually exceed natives, ceteris paribus.

Multiple studies reinforced Chiswick's findings (Carliner 1980; Borjas 1982; Abbott and Beach 1993). However, subsequent work questioned the extent to which immigrants are positively selected and, in turn, their ability to exceed native labor market outcomes with time in the U.S. (Borjas 1985; Borjas 1995). Although there are important and outstanding questions in this literature regarding the degree of selection and assimilation, on net, the existing evidence shows some degree of assimilation in terms of earnings for most immigrant groups (Lubotsky 2007; Beenstock, Chiswick et al. 2010; Chiswick and Miller 2011; Chiswick and Miller 2012). What we address is whether the economic assimilation extends to smoking-related fringe benefits. These benefits may proxy for a broader class of employment features that affect health and, in turn, healthcare costs and productivity. The topic of access to fringe benefits in general 
has received less attention than wages but is also important, as these benefits may hold value for individuals. It becomes an empirical issue because fringe benefits and wages may be complements ('good' jobs feature both) or substitutes (compensating differentials).

A related concept is the reputed healthy immigrant effect. On arrival to the host country immigrants are believed to have better health than natives. This effect may be attributable to positive selection on health into immigration, domestic legislative rules on who can immigrate, and better health habits in the sending countries (Hull 1979; Kennedy, McDonald et al. 2006). However, immigrant health appears to assimilate towards native levels over time (Hull 1979; Marmot, Adelstein et al. 1984; Palloni and Morenoff 2001; Anson 2004; Kaplan, Huguet et al. 2004; Antecol and Bedard 2006; Hao and Kim 2009; Park, Myers et al. 2009). Potential mechanisms for the decline in immigrant health include uptake of host county's poorer health behaviors (e.g., smoking, consumption of high calorie foods, sedentary lifestyles, substance misuse) and under-reporting of health conditions at migration (Antecol and Bedard 2006; Kennedy, McDonald et al. 2006; Biddle, Kennedy et al. 2007). It is not clear the extent to which the healthy immigrant effect, if present, will influence access to smoking-related fringe benefits.

\subsection{Ethnic enclaves}

An ethnic enclave is a physical space with high ethnic concentration and is culturally distinct from the larger society. Immigrants often live in the enclave as they establish themselves in the new country (Bartel 1989; Borjas 1998). Residing in the enclave at arrival may be a rational decision for many as shared language, social networks, and cultural norms within the enclave that may lower the costs (both pecuniary and non-pecuniary) to immigration. As articulated by Bertrand, Luttmer et al. (2000) enclave residence may improve employment 
outcomes through information (e.g., employment opportunity knowledge, job referral networks) and social norms (e.g., attitudes toward working, self-employment, work effort).

Perhaps not surprisingly, the research on enclaves is mixed. Residence in an enclave has been shown to affect immigrant employment outcomes both negatively (Bertrand, Luttmer et al. 2000; Collins and Margo 2000; Warman 2007; Liu 2009; Kondylis 2010) and positively (Edin, Fredriksson et al. 2003; Damm 2009; Bell and Machin 2013). There is evidence of negative selection into enclaves: less able immigrants are more likely to reside in enclaves (Damm 2009). Such selection suggests that enclaves may not provide high quality information and social norms. Further complicating analyses, immigrant characteristics (e.g., skill level, country of origin, popular occupations) may determine whether enclave residence affects these outcomes (Borjas 2005; Åslund and Fredriksson 2009; Beaman 2012; Patel and Vella 2012). If residence in the enclave affects the quality of jobs immigrants are able to obtain, then we might expect enclave residence to be associated with immigrants' access to smoking-related fringe benefits as well.

\section{Data and empirical model}

\subsection{Current Population Survey Tobacco Use Supplement Data}

We draw from the Current Population Survey (CPS) Tobacco Use Supplements

(TUS). These data are the best available for our research questions as they contain detailed information on smoking-related fringe benefits, and immigrant status and sending country. The TUS were administered as a supplement to the basic monthly CPS in 1992 to 1993, 1995 to 1996, 1998 to 1999,2000 to 2003, 2006 to 2007, and 2010 to 2011. Beginning in 1995, all CPS TUS respondents were asked about their country of birth (this question was added to the CPS in 1994, but the TUS was not fielded in that year). Thus we restrict our sample to the 1995 to 2011 TUS surveys which include 1,609,332 respondents. 
We make several exclusions to construct our analysis sample. First, we exclude respondents in the 2000 TUS $(N=166,176)$ as this supplement does not collect information on our smoking-related fringe benefit measures (described in Section 3.2). Second, we exclude proxy-respondents as information on our outcomes is only collected from self-respondents $(N=337,775)$. Third, we drop respondents younger than 18 years as TUS fielded after 2006 do not include such individuals $(N=44,807)$. Fourth, we exclude TUS respondents for which we do not have information on metropolitan statistical area (MSA) of residence $(N=330,723)$ as we use this information to construct our ethnic enclave proxy (defined in Section 3.2). Respondents who cannot be linked to an MSA reside in areas, typically rural, that are masked by TUS administrators for confidentiality purposes. Our smoking-related fringe benefits are only asked of respondents who are employed, and work for pay in government and private for-profit jobs; this is the relevant population for these questions. Thus, we exclude 263,697 non-employed respondents and 33,583 respondents who do not work for either a private for-profit or government employer. Lastly, we exclude respondents with missing information on birth country $(N=9,392)$. We exclude additional observations due to missing information on our smoking-related fringe benefit variables (described in Section 3.2). Our final analysis sample includes 311,270 natives and 43,910 immigrants. In unreported analyses we compared our analysis sample to the full TUS sample. In general, the samples are broadly similar in terms of demographics. However, our analysis sample is more urban than the full TUS sample, which is to be expected given that we exclude respondents for which we do not have MSA information (such observations are disproportionately rural residents).

\subsection{Smoking-related fringe benefits}


We next construct a set of separate indicator variables that measure 1) access to an office smoking ban; 2) report of an unenforced office smoking ban (a firm may have a ban on the books, as many states regulate smoking in the workplace during our study period and employers often implement voluntary bans, but may chose not to enforce the ban; this question is asked only to respondents who report an office smoking ban); and 3) access to an office smoking cessation program (questions 2 and 3 are not asked in the 2003 TUS). As noted earlier, these variables are asked only of respondents who report working for pay at government or for-profit jobs, and are not self-employed. Moreover, the smoking ban questions are asked only to respondents who report primarily working indoors. Thus, our analysis is potentially vulnerable to sample selection bias. In unreported analyses we find that immigrant status is associated with a 2.4 percentage point reduction in the probability of appearing in our sample. We note sample selection as a limitation of the study.

Employment at a worksite that bans smoking protects against ETS, may increase the hassle cost of smoking, and may make the social norm to be less supportive of smoking at work. These in turn would reduce the impacts of ETS. Of course a ban that is not well enforced will not be as protective. Access to workplace smoking cessation programs can influence smoking by reducing the costs (monetary and non-monetary) of cessation. Medical evidence suggests that worksite smoking cessation programs are effective in promoting cessation (Volpp, Troxel et al. 2009). These would result in fewer smokers and less exposure to ETS effects.

\subsection{Assimilation}

To proxy for assimilation, we follow the economics literature and construct a linear measure of years since migration to the U.S. Respondents are asked for the year in which they entered the U.S. This variable is categorical, and we assign the mid-point year to each interval. 
When the mid-point year is not an integer (e.g., 1966.5) we round up to the nearest integer. An exception is when entry date is truncated. For example, in the 2003 TUS, the earliest value is "before 1950" and we assign immigrants an entry year of 1950. This imputation underestimates the years since migration for early arrivers. We then subtract the year of entry from the survey year to determine the years since migration. A limitation is that there is no data on reverse migration; thus the variable overestimates years in the U.S. for those immigrants who return to the home country at some point between the reported year of entry and the survey year.

\subsection{Ethnic enclave}

We use data from the 1990 and 2000 5\% file of the U.S. Censuses and the 2005 to 2011 American Community Surveys (ACS) to construct our ethnic enclave measures (we do not use the 2001 to 2004 ACS data as they do not contain MSA information). Both data sets were extracted from the Integrated Public Use Microdata Series (Ruggles, Alexander et al. 2010) and contain detailed information on birth country. We limit the sample to the top 50 sending countries in the 1990 Census as sample sizes for particular countries become small outside this range. These countries comprise over $86 \%$ of immigrants in the TUS. Table 1 lists the top 50 countries, the number of respondents from each country in our analysis sample, the smoking rate in these countries in either 2006 or 2009 from external sources (Leung 2013; World Health Organization 2013), and the smoking rate for each country based on our analysis sample. An interesting feature of this table is that many immigrants in our sample arrive from countries with higher smoking rates than the U.S. For example, the smoking rate in Greece is $52 \%$, substantially higher than the U.S. rate. However, TUS sample smoking rates are lower than the country rates for all countries suggesting positive selection on smoking into immigration (Puerto Rico, which we treat as a separate country from the U.S., and Panama are exceptions). 
We construct our proxy for ethnic enclaves as the percent of individuals from the same birth country in the MSA of residence. For example, if a respondent reports that he was born in Ireland and resides in the New York City MSA (NYC), we assign him the following value:

$\frac{(\text { population born in Ireland })_{N Y C, t}}{{\text { (total population })_{N Y C, t}}_{10}} * 100$. See the Data Appendix for more details on construction of this variable. Although it may be appealing to define the enclave at a smaller geographic level (e.g., census track), the finest geographic unit available for a substantial proportion of TUS respondents is the MSA. The TUS contain information on county of residence for roughly $30 \%$ of respondents, but sample sizes become too small to yield meaningful results and we chose not to utilize this information in our study. We view our MSA-level measure as a proxy for access to enclaves. Put differently, an immigrant who lives in an MSA with a higher percent of ownethnics likely has better access to an enclave than an otherwise similar immigrant with a lower percent own-ethnic in his MSA of residence.

\subsection{State anti-smoking policies}

We include two standard state government anti-smoking policies in our regression models: mandated venue-specific smoking bans (Centers for Disease Control and Prenvetion 2012) and the state cigarette tax in dollars (Orzechowski and Walker 2012). We include an index for the sum of bans in worksites (both private and government worksites, this variable ranges from 0 to 6 ) and the sum of bans in other venues (shopping malls, restaurants, and bars, this variable ranges from 0 to 9). Higher scores indicate more restrictive regulation. We convert cigarette taxes to 2011 dollars using the Consumer Price Index (CPI).

\subsection{Other control variables}

In all regression models we include indicators for age ( 25 to 34 years, 35 to 44 years, 45 to 54 years, 55 to 64 years, and 65 and above years, with 18 to 24 years as the omitted category), 
race/ethnicity (African American, Hispanic, and other race, with white as the omitted category), educational attainment (high school, some college, college graduate, and post college, with less than high school as the omitted category), and marital status (divorced, separated, or widowed, and never married, with married as the omitted category). To preserve sample size, we include indicators for observations with missing information in our regression models.

\subsection{Empirical model}

In this section we describe our empirical strategy for estimating the association between assimilation and ethnic enclave residence, and smoking-related fringe benefits. To this end, we estimate two sets of regressions. First, we pool natives and immigrants and compare outcomes across these groups. These regressions allow us to assess differences in smoking-related fringe benefit access by immigrant status. Second, we focus on assimilation and ethnic enclave residence using a sample of immigrants only.

Our first set of regressions take the following form:

(1) $S_{i m t}=\alpha_{0}+\alpha_{1} I_{i m t}+X_{i m t} \alpha_{2}+P_{s t} \alpha_{3}+M_{m} \alpha_{4}+D_{t} \alpha_{5}+\varepsilon_{i m t}$

$S_{\text {imt }}$ is smoking-related fringe benefit for individual $i$ residing in MSA $m$ in year $t$. The key explanatory variable is $I_{i m t}$, an indicator variable taking the value of one for immigrants and zero otherwise. $P_{s t}$ is a vector of state anti-smoking policies, and $X_{i m t}$ is a vector of personal characteristics. $M_{m}$ and $D_{t}$ are vectors of MSA and year fixed effects. $\varepsilon_{i b m t}$ is the error term.

The second set of regressions we estimate take the following form:

(2) $S_{i b m t}=\beta_{0}+\beta_{1} A_{i b m t}+\beta_{2} E_{b m t}+P_{s t} \beta_{3}+X_{i b m t} \beta_{4}+B_{b} \beta_{5}+M_{m} \beta_{6}+D_{t} \beta_{7}+\eta_{i b m t}$

The key predictor variables are $A_{i b m t}$ (years since migration) and $E_{b m t}$ (percent of MSA own-ethnic). $B_{b}$ is a vector of birth country fixed effects. Other variables are as defined above. 
Inclusion of birth country fixed effects in Equation (2) controls for difficult to observe characteristics that are correlated with birth country and our outcomes. Moreover, inclusion of these fixed effects partially addresses non-random selection into migration that may vary by birth country (i.e., time-invariant propensity to immigrate to the U.S.). By including MSA fixed effects in our regression models we utilize within MSA variation in our predictor variables to estimate relationships. As noted by Borjas (1985) years since migration and survey year linearly determine the year of arrival in a pooled cross-sectional analysis as utilized here. Thus, the survey year fixed effects control for cohort effects (e.g., changes in cohort quality that occur over time). The year fixed effects also capture national trends in smoking-related fringe benefits.

We utilize a linear probability model (LPM) as our outcomes are binary (we chose the LPM over a probit or logit for tractability, but results are comparable if we apply a probit and estimate average marginal effects). We cluster standard errors around the MSA, although results are robust to clustering at alternative levels (e.g., state, birth country). Results are unweighted, but results are comparable if we instead apply sample weights. All models are estimated separately by sex given different labor market and immigration patterns across men and women.

\section{Results}

\subsection{Summary statistics}

Tables 2A (men) and 2B (women) report summary statistics for the full sample, native sample, and immigrant sample. In the full sample $91 \%$ of women and $88 \%$ of men report an office smoking ban. However, $5 \%$ of women and $9 \%$ of men report that the smoking bans in their offices are not enforced. $21 \%$ of women and $20 \%$ of men have access to a smoking cessation program through their employer. Considering natives and immigrants separately, the descriptive statistics suggest that, on average, immigrants have lower access than natives to 
some, but not all, smoking-related fringe benefits. Specifically, natives have better access to office smoking bans and smoking cessation programs. There is, however, no difference by immigrant status in the probability of reporting an unenforced ban among women and native men are more likely to report an unenforced ban than immigrant men.

The average number of years since migration to the U.S. among immigrant women and men is 20 and 17 respectively. Immigrant women and men live in MSAs with $1.9 \%$ and $2.3 \%$ of the population from their country of birth respectively. Immigrants tend to reside in states with more restrictive smoking policies, as measured by venue-specific smoking bans and cigarette taxes. Comparison of demographics suggests that immigrants are less advantaged than natives.

\subsection{Regression results: Full sample}

Table 3 reports selected regression results for the full sample; that is we pool natives and immigrants and consider differences in access to smoking-related fringe benefits after conditioning on observable characteristics. We also report coefficient estimates on the government mandated worksite smoking bans to observe whether these bans are passed through to workers. A full set of coefficient estimates is available on request. As noted earlier, there are differences in sample sizes across outcome variables due to differences in survey skip patterns, question availability across TUS, and participant response patterns.

Among women, we find that immigrants are less likely to work in jobs that ban smoking in the workplace and offer smoking cessation programs (1.97 and 2.02 percentage points, or 2.17 and 9.84\%). We find no statistically significant evidence that immigrant women are more or less likely than native women to report unenforced office smoking bans. Turning to men, we find that immigrant status is strongly associated with all three measures of smoking-related fringe benefits examined in this study. In particular, male immigrants are less likely to work in jobs 
that ban smoking in the office (1.92 percentage points or $2.18 \%)$ and are less likely to have access to a smoking cessation program in their office (4.11 percentage points or $21.44 \%$ ) than native males. However, conditional on reporting an office smoking ban, immigrant males are less likely to report unenforced bans than natives males (1.18 percentage points or $13.08 \%)$.

We find evidence that government mandated venue-specific smoking bans are passed on to male, but not female, immigrant workers in our sample: more restrictive state worksite smoking bans lead to an increase in the probability of reporting an office smoking ban among males. We do not find evidence that mandated bans lead to changes in the probability of reporting an unenforced ban (conditional on reporting a ban in the office): coefficients are small in magnitude and statistically indistinguishable from zero. In unreported analyses we interact the immigrant variable with the worksite smoking ban index to assess whether there is differential policy pass through by immigrant status. Our findings suggest that government mandated worksite smoking bans are passed through to native, but not immigrant, male workers.

\subsection{Regression results: Immigrant sample}

Next, we focus our attention exclusively on immigrants to study how assimilation and ethnic enclave residence may influence access to smoking-related fringe benefits (put differently, we drop natives from our analysis sample). Results are reported in Table 4. Among female immigrants, assimilation is positively associated with the probability of reporting an office smoking ban and cessation program, and negatively associated with reporting an unenforced office smoking ban. All coefficient estimates are precisely estimated $(p<0.01)$. Specifically, an additional year in the U.S. is associated with a 0.16 and 0.24 percentage point $(0.18$ and $1.14 \%)$ increase in the probability of reporting an office smoking ban and cessation program, and a 0.06 percentage point $(1.3 \%)$ reduction in the probability of reporting an unenforced office smoking 
ban. Percent own-ethnic in the MSA of residence, our proxy for ethnic enclave residence, is only statistically associated with the probability of reporting access to smoking-related fringe benefits in one out of three cases. So there is little evidence to support a relationship.

Turning to male immigrants, we find that assimilation is associated with increased probability of reporting an office smoking ban and cessation program, but we find no statistically significant evidence that assimilation is associated with the probability of reporting an unenforced ban. An additional year in the U.S. is associated with a 0.16 percentage point $(0.19 \%)$ increase in the probability of reporting an office smoking ban and a 0.19 percentage point $(1.54 \%)$ increase in the probability of reporting an office smoking cessation program. We find no evidence that ethnic enclave residence is linked with smoking-related fringe benefits.

Among female immigrants, we find that government mandated worksite smoking bans are associated with lower a lower probability of reporting an unenforced office smoking ban but not the probability of the ban. Among male immigrants, all coefficients on government mandated worksite smoking bans are statistically insignificant. These findings are consistent with the estimates generated in the full sample regressions.

\subsection{Potential mechanisms}

Our findings suggest that, although immigrants have lower access to smoking-related fringe benefits, assimilation into U.S. society allows immigrants to access such benefits while residence in an ethnic enclave is largely unassociated with these outcomes. We next attempt to shed some light on potential mechanisms for these findings.

To this end, we estimate regressions in the immigrant sample that model family income inflated to 2011 dollars (we view this as a proxy, albeit imperfect, for labor market earnings) and an indicator for employment in a white collar job as a function of assimilation, ethnic enclave 
residence, and other variables included in Equation (2). Ideally we would like to consider more standard measures of labor market success such as wages or earnings. However the TUS, unlike other supplements to the CPS such as the Annual Social and Economic Supplement ('March Supplement'), contains a limited set of employment measures as it is primarily designed to collect information on smoking-related outcomes. We use least squares to estimate income regressions and a linear probability model to estimate white collar employment regressions. We include respondents who provide a valid response to at least one of our smoking-related fringe benefits to minimize concerns regarding compositional changes in the sample.

Results are reported in Table 5. Consistent with previous research, we find that assimilation is associated with higher family income and higher probability of working in a white collar job among both male and female workers. One interpretation of these findings is that access to higher quality jobs (as measured by income and occupation) may also allow immigrants to access fringe benefits designed to promote health. Ethnic enclave residence is unassociated with income and probability of white collar work among female immigrants. However, our proxy for ethnic enclave residence is negatively associated the probability of a white collar job among male immigrants.

In unreported analyses we considered the potential influence of assimilation and enclave residence on the probability of reporting smoking at the time of the TUS interview. Our results suggest that assimilation is associated with higher probability of smoking among women but is not associated with this probability among men, although the coefficient carries a negative sign. One possible explanation is women and men assimilate by moving toward the U.S. sex-specific smoking norms, and female immigrants tend to smoke less than female natives while male 
natives smoke more. We do not find any evidence that enclave residence is associated with the probability of smoking among men or women.

\section{Robustness checks}

We next examine the robustness of our findings to a number of sensitivity checks to assess the stability of our findings. The results are discussed below and are available on request.

\subsection{Defining the enclave at an alternative geographic level}

In our core regressions, we construct our measure of the ethnic enclave at the MSA level. However, this requires that we exclude respondents that cannot be linked to MSA of residence information. Further, respondents that cannot be linked to MSA information are more likely to be rural thus this exclusion may impose sample selection bias. We next re-construct our enclave measures at the state level. A tradeoff here is that the state is likely an even cruder measure of the enclave than the MSA, but the benefit is that we do not exclude rural respondents and sample selection concerns are minimized. Moreover, we are able to utilize additional ACS surveys, specifically the 2001 to 2004 surveys, in our enclave construction algorithm as all ACS surveys contain state of residence information (in contrast to MSA of residence). Thus less imputation is required to construct the enclave measure. More details on variable construction are available on request. We re-estimate Equation (2) using our state-level enclave measures and results, available on request, are highly comparable to those reported in the manuscript.

\subsection{Addressing between state unobservables}

In our core models we control for MSA fixed effects as we construct our measure of the ethnic enclave at this level. We measure our state policies at a higher level of aggregation, however. To better address difficult-to-observe characteristics that are correlated with both the state policies and our outcome variables we replace the MSA fixed effects with state fixed 
effects and re-estimate our models. The findings, available on request, are consistent in terms of sign, magnitude, and statistical significance to the results reported in this manuscript. We attempted to utilize an instrumental variable framework following Bertrand, Luttmer et al. (2000), but our IVs were underpowered and we chose not to present these findings.

\subsection{Synergistic effects}

The regressions reported thus far assume that assimilation and ethnic enclave residence are additively separable. We next relax this assumption by interacting the assimilation and ethnic enclave variables and re-estimate Equation (2) in the immigrant sample. In all regressions, the coefficients on the interaction terms are small in magnitude and statistically indistinguishable from zero. Thus, these analyses do not suggest strong evidence of synergistic effects between assimilation and enclave residence.

\subsection{Compositional effects}

To preserve sample size, thus far in the analysis we have included all respondents who provide valid information on outcome and control variables. A concern here is that there may be differences in the composition of the sample across specifications due to differences in sample size across outcomes (as discussed in Section 3.2). To address this concern, we retain only those respondents who have complete information on all three outcome variables and re-estimate Equations (1) and (2). Results are comparable, although less precisely estimated as we lose a substantial amount of sample size, to those reported in our main tables and suggest that changes in sample composition are not driving our findings.

\section{Conclusions}

In this study we provide new evidence on the roles of economic assimilation and enclave residence in immigrant access to smoking-related fringe benefits. We argue that these fringe 
benefits are themselves interesting as they offer protection from ETS-related health harms. To the extent that they also promote smoking cessation, they also offer financial benefits in the form of reduced expenditures on tobacco products and healthcare (both private and public). In addition, smoking-related fringe-benefits may proxy for a broader class of health-related fringe benefits that have received little attention from economists, but may hold great value for individuals. This hypothesis of correlated benefits is supported as data on employer-offered benefit packages suggest positive correlations across health-related fringe benefits e.g., healthy eating programs, employee assistance programs, smoking cessation programs (The Kaiser Family Foundation and Health Research \& Educational Trust 2012).

Several patterns emerge from our analysis. First, we show that immigrants have lower access to smoking-related fringe benefits than natives. One exception is that immigrant men are less likely to report an unenforced office smoking ban than native men. Second, we find that assimilation into U.S. society allows immigrants to gain access to smoking-related fringebenefits, although this finding is stronger among women than men. Residence in an ethnic enclave is unrelated to immigrants' access to smoking-related fringe benefits considered here. Lastly, we find only limited evidence that government mandated worksite smoking bans are passed on to immigrant workers. This finding suggests that there may be groups within the population that are not reached by government interventions designed to improve health.

While we extend the literature in multiple dimensions and use a rich and extensive data set, the study has several limitations. Although we address selection into migration, at least partially by including birth country fixed effects in our regressions, it is unlikely that we are able to address all sources of bias. Moreover, we are unable to adequately account for compositional changes among the immigrant population over time (inclusion of survey fixed effects addresses 
this concern to some extent). Our measure of assimilation is vulnerable to both rounding error and recall bias, and does not account for periods of reverse migration. Lastly our proxy measure for ethnic enclave residence is arguably crude and measured at the MSA level rather than a smaller, more desirable level (e.g., census track).

Our findings suggest that assimilation and integration into U.S. society not only allows immigrants to access jobs that offer higher wages, but it also allows these individuals to gain protection from ETS in the workplace and access to employer-sponsored smoking cessation programs. This access can improve immigrants' health and, potentially, productivity in the labor market. However, we do not find evidence that ethnic enclave residence either helps or hinders immigrants' access to these benefits. We do not find evidence consistent with the idea that immigrants 'pay for' their access to smoking-related fringe benefits in the form of lower wage benefits (which we proxy, admittedly imperfectly, with family income). However, this is not a central aim of our study and we offer only suggestive evidence in that assimilation results in higher family income. Although theory unambiguously predicts that wage compensation should fall as non-wage compensation (e.g., fringe benefits) rises, the empirical evidence on the existence of compensating differentials is mixed (Gruber 1994; Jensen and Morrisey 2001; Levy and Feldman 2001; Simon 2001; Miller 2004). Future research could consider the influence of assimilation and ethnic enclave residence on other forms of non-monetary compensation such as employee assistance programs and health insurance. Such research could broaden our understanding of immigrants' integration into the U.S. 
Table 1. Top 50 immigrant sending countries

\begin{tabular}{|c|c|c|c|c|}
\hline Birth County & Order & $\mathbf{N}$ & $\begin{array}{c}\text { Country } \\
\text { smoking rate }\end{array}$ & $\begin{array}{c}\text { Analysis sample } \\
\text { smoking rate }\end{array}$ \\
\hline Mexico & 1 & 11,490 & 0.26 & 0.14 \\
\hline Philippines & 2 & 2,866 & 0.29 & 0.11 \\
\hline India & 3 & 2,292 & 0.15 & 0.06 \\
\hline Puerto Rico & 4 & 1,737 & 0.11 & 0.19 \\
\hline Germany & 5 & 1,701 & 0.29 & 0.24 \\
\hline China & 6 & 1,617 & 0.27 & 0.05 \\
\hline El Salvador & 7 & 1,597 & 0.22 & 0.09 \\
\hline Canada & 8 & 1,383 & 0.20 & 0.15 \\
\hline Cuba & 9 & 1,348 & 0.39 & 0.15 \\
\hline Vietnam & 10 & 1,202 & 0.25 & 0.17 \\
\hline England & 11 & 1,067 & 0.24 & 0.16 \\
\hline Dominican Republic & 12 & 996 & 0.15 & 0.09 \\
\hline Jamaica & 13 & 991 & 0.24 & 0.06 \\
\hline Korea (Republic of Korea) & 14 & 897 & 0.28 & 0.20 \\
\hline Colombia & 15 & 781 & 0.27 & 0.10 \\
\hline Guatemala & 16 & 781 & 0.13 & 0.09 \\
\hline Japan & 17 & 778 & 0.27 & 0.21 \\
\hline Poland & 18 & 704 & 0.31 & 0.21 \\
\hline Haiti & 19 & 684 & -- & 0.05 \\
\hline Russia & 20 & 636 & 0.42 & 0.19 \\
\hline Ecuador & 21 & 555 & 0.15 & 0.08 \\
\hline Italy & 22 & 550 & 0.26 & 0.16 \\
\hline Peru & 23 & 462 & 0.23 & 0.12 \\
\hline Taiwan & 24 & 457 & -- & 0.08 \\
\hline Honduras & 25 & 427 & -- & 0.11 \\
\hline Iran & 26 & 405 & 0.14 & 0.12 \\
\hline Portugal & 27 & 379 & 0.24 & 0.14 \\
\hline Hong Kong & 28 & 354 & -- & 0.11 \\
\hline Brazil & 29 & 348 & 0.17 & 0.13 \\
\hline Guyana/British Guiana & 30 & 346 & 0.16 & 0.06 \\
\hline Nicaragua & 31 & 336 & -- & 0.11 \\
\hline France & 32 & 317 & 0.31 & 0.23 \\
\hline Laos & 33 & 312 & 0.28 & 0.13 \\
\hline Trinidad and Tobago & 34 & 310 & 0.19 & 0.11 \\
\hline Thailand & 35 & 271 & 0.24 & 0.16 \\
\hline Ireland & 36 & 221 & 0.32 & 0.19 \\
\hline Argentina & 37 & 205 & 0.27 & 0.13 \\
\hline Cambodia (Kampuchea) & 38 & 195 & 0.23 & 0.09 \\
\hline Spain & 39 & 192 & 0.32 & 0.24 \\
\hline Panama & 40 & 186 & 0.11 & 0.11 \\
\hline Yugoslavia & 41 & 181 & -- & 0.32 \\
\hline Romania & 42 & 179 & 0.35 & 0.16 \\
\hline Greece & 43 & 177 & 0.52 & 0.27 \\
\hline Israel/Palestine & 44 & 175 & 0.21 & 0.16 \\
\hline Scotland & 45 & 163 & 0.24 & 0.23 \\
\hline Lebanon & 46 & 159 & 0.39 & 0.12 \\
\hline Netherlands & 47 & 132 & 0.29 & 0.16 \\
\hline Hungary & 48 & 116 & 0.38 & 0.22 \\
\hline Czechoslovakia & 49 & 115 & 0.37 & 0.17 \\
\hline Austria & 50 & 77 & 0.46 & 0.22 \\
\hline
\end{tabular}

Notes: We deleted entries that could not be exactly match to country. Examples of deleted entries are abroad (not specified), Africa (not specified), and Americas (not specified). Country smoking rates pertain to 2006 or 2009 (Leung 2013; World Health Organization 2013). -- indicates that data for this country is not available. 
Table 2A. Summary statistics among women: Tobacco Use Supplements 1995-2011

\begin{tabular}{|c|c|c|c|c|}
\hline Variable & Full sample & Natives & Immigrants & $\begin{array}{c}\text { Difference } \\
\text { (p-value) }\end{array}$ \\
\hline \multicolumn{5}{|l|}{ Outcomes } \\
\hline Office smoking ban & 0.9091 & 0.9128 & 0.8793 & 0.000 \\
\hline Office smoking ban not enforced & 0.0512 & 0.0510 & 0.0530 & 0.298 \\
\hline Office smoking cessation program & 0.2052 & 0.2103 & 0.1620 & 0.000 \\
\hline \multicolumn{5}{|l|}{ Immigration variables } \\
\hline Immigrant & 0.1083 & -- & -- & -- \\
\hline Years since migration & 3.0049 & -- & 19.5093 & -- \\
\hline Percent own ethnic in MSA & 80.2098 & 89.7276 & 1.8582 & 0.000 \\
\hline \multicolumn{5}{|l|}{ State level controls } \\
\hline Worksite smoking ban index (0-6) & 2.7775 & 2.7185 & 3.2633 & 0.000 \\
\hline Other venue smoking ban index (0-9) & 2.5668 & 2.4644 & 3.4099 & 0.000 \\
\hline Cigarette tax (dollars) & 0.8756 & 0.8566 & 1.0322 & 0.000 \\
\hline \multicolumn{5}{|l|}{ Demographics } \\
\hline Age & 40.8670 & 40.9471 & 40.2073 & 0.000 \\
\hline White & 0.8222 & 0.8432 & 0.6498 & 0.000 \\
\hline African American & 0.1246 & 0.1299 & 0.0813 & 0.000 \\
\hline Other race & 0.0531 & 0.0269 & 0.2689 & 0.000 \\
\hline Hispanic & 0.0930 & 0.0533 & 0.4195 & 0.000 \\
\hline Less than high school & 0.0686 & 0.0519 & 0.2063 & 0.000 \\
\hline High school & 0.2781 & 0.2823 & 0.2429 & 0.000 \\
\hline Some college & 0.3151 & 0.3259 & 0.2264 & 0.000 \\
\hline College degree & 0.3382 & 0.3399 & 0.3244 & 0.000 \\
\hline Married & 0.5295 & 0.5230 & 0.5832 & 0.000 \\
\hline Divorced/separated/widowed & 0.2224 & 0.2252 & 0.2000 & 0.000 \\
\hline Never married & 0.2481 & 0.2519 & 0.2168 & 0.000 \\
\hline $\mathrm{N}$ & 190,495 & 169,861 & 20,634 & \\
\hline
\end{tabular}

Notes: Differences estimated with $\chi^{2}$-tests when the outcome is binary and $t$-tests when the outcome is continuous. The sample utilized to generate summary statistics includes respondents that provided valid information on one of the three outcome variables we study, thus sample proportions do not exactly match sample proportions reported in tables that report regression results. 
Table 2B. Summary statistics among men: Tobacco Use Supplements 1995-2011

\begin{tabular}{|c|c|c|c|c|}
\hline Variable & Full sample & Natives & Immigrants & $\begin{array}{c}\text { Difference } \\
\text { (p-value) }\end{array}$ \\
\hline \multicolumn{5}{|l|}{ Outcomes } \\
\hline Office smoking ban & 0.8789 & 0.8838 & 0.8476 & 0.000 \\
\hline Office smoking ban not enforced & 0.0902 & 0.0915 & 0.0814 & 0.004 \\
\hline Office smoking cessation program & 0.1917 & 0.2028 & 0.1233 & 0.000 \\
\hline \multicolumn{5}{|l|}{ Immigration variables } \\
\hline Immigrant & 0.1413 & -- & - & -- \\
\hline Years since migration & 3.2713 & -- & 17.0700 & -- \\
\hline Percent own ethnic in MSA & 77.3040 & 89.6567 & 2.2573 & 0.000 \\
\hline \multicolumn{5}{|l|}{ State level controls } \\
\hline Worksite smoking ban index (0-6) & 2.7825 & 2.7248 & 3.1327 & 0.000 \\
\hline Other venue smoking ban index (0-9) & 2.6063 & 2.4920 & 3.3010 & 0.000 \\
\hline Cigarette tax (dollars) & 0.8703 & 0.8502 & 0.9925 & 0.000 \\
\hline \multicolumn{5}{|l|}{ Demographics } \\
\hline Age & 40.4846 & 40.7523 & 38.8584 & 0.000 \\
\hline White & 0.8549 & 0.8800 & 0.7018 & 0.000 \\
\hline African American & 0.0870 & 0.0921 & 0.0563 & 0.000 \\
\hline Other race & 0.0581 & 0.0279 & 0.2418 & 0.000 \\
\hline Hispanic & 0.1167 & 0.0517 & 0.5118 & 0.000 \\
\hline Less than high school & 0.0950 & 0.0617 & 0.2974 & 0.000 \\
\hline High school & 0.2694 & 0.2765 & 0.2261 & 0.000 \\
\hline Some college & 0.2748 & 0.2926 & 0.1667 & 0.000 \\
\hline College degree & 0.3608 & 0.3692 & 0.3098 & 0.000 \\
\hline Married & 0.6004 & 0.5907 & 0.6598 & 0.000 \\
\hline Divorced/separated/widowed & 0.1275 & 0.1341 & 0.0872 & 0.000 \\
\hline Never married & 0.2721 & 0.2753 & 0.2530 & 0.000 \\
\hline $\mathrm{N}$ & 164,685 & 14,1409 & 23,276 & \\
\hline
\end{tabular}

Notes: Differences estimated with $\chi^{2}$-tests when the outcome is binary and $t$-tests when the outcome is continuous. The sample utilized to generate summary statistics includes respondents that provided valid information on one of the three outcome variables we study, thus sample proportions do not exactly match sample proportions reported in tables that report regression results. 
Table 3. Smoking-related fringe benefits regression results for full sample: Tobacco Use Supplements 19952011

\begin{tabular}{lccc}
\hline \hline & $\begin{array}{c}\text { Office } \\
\text { smoking ban }\end{array}$ & $\begin{array}{c}\text { Office smoking ban } \\
\text { not enforced }\end{array}$ & $\begin{array}{c}\text { Office smoking } \\
\text { cessation program }\end{array}$ \\
\hline Sample: women & & & 0.2052 \\
\hline Sample proportion & 0.9091 & 0.0512 & $-0.0202^{* * *}$ \\
\hline Immigrant & $-0.0197 * * *$ & $(0.0042)$ \\
& $(0.0044)$ & -0.0031 & -0.0023 \\
Worksite smoking ban index & 0.0019 & $(0.0026)$ & $(0.0024)$ \\
\hline N & $(0.0012)$ & -0.0014 & 148,180 \\
\hline Sample: men & 182,355 & $10.0010)$ & 0.1917 \\
\hline Sample proportion & & & $-0.0411 * * *$ \\
\hline Immigrant & 0.8789 & 0.0902 & $(0.0048)$ \\
Worksite smoking ban index & $-0.0192 * * *$ & $-0.0118 * * *$ & -0.0016 \\
& $(0.0044)$ & $(0.0032)$ & $(0.0021)$ \\
\hline N & $0.0062 * * *$ & -0.0025 & 134,921 \\
\hline
\end{tabular}

Notes: All models estimated with a linear probability model and adjust for individual demographics; state cigarette tax; state smoking ban index for shopping malls, restaurants, and bars; MSA fixed effects; and year fixed effects. Standard errors clustered around the MSA and are reported in parentheses. Sample sizes differ across outcomes based on skip patterns in the TUS, differential availability of survey items across survey years, and differential response probabilities.

$* * * ; * *$; and $*=$ statistically different from zero at the $1 \% ; 5 \%$; and $10 \%$ confidence level. 
Table 4. Smoking-related fringe benefits regression results for immigrant sample: Tobacco Use Supplements 1995-2011

\begin{tabular}{lccc}
\hline \hline & $\begin{array}{c}\text { Office } \\
\text { smoking ban }\end{array}$ & $\begin{array}{c}\text { Office smoking ban } \\
\text { not enforced }\end{array}$ & $\begin{array}{c}\text { Office smoking } \\
\text { cessation program }\end{array}$ \\
\hline Sample: women & & & 0.1620 \\
\hline Sample proportion & 0.8793 & 0.0530 & $0.0024^{* * *}$ \\
\hline Years since migration & $0.0016^{* * *}$ & $-0.0006^{* * *}$ & $(0.0003)$ \\
Percent own-ethnic & $(0.0002)$ & $(0.0001)$ & -0.0002 \\
& -0.0010 & 0.0008 & $(0.0011)$ \\
Worksite smoking ban index & $(0.0016)$ & $(0.0005)$ & -0.0050 \\
& -0.0022 & $-0.0055^{* *}$ & $(0.0054)$ \\
\hline N & $(0.0042)$ & $(0.0027)$ & 15,605 \\
\hline Sample: men & 19,733 & 14,923 & 0.1233 \\
\hline Sample proportion & & 0.0814 & $0.0019^{* * *}$ \\
\hline Years since migration & 0.8476 & -0.0002 & $(0.0003)$ \\
Percent own-ethnic & $0.0016 * * *$ & $(0.0002)$ & -0.0013 \\
Worksite smoking ban index & $(0.0002)$ & 0.0002 & $(0.0010)$ \\
\hline N & -0.0003 & $(0.0011)$ & -0.0028 \\
\hline Notes: All & $(0.0014)$ & -0.0016 & $(0.0038)$ \\
\hline
\end{tabular}

Notes: All models estimated with a linear probability model and adjust for individual demographics; state cigarette tax; state smoking ban index for shopping malls, restaurants, and bars; MSA fixed effects; birth country fixed effects; and year fixed effects. Standard errors clustered around the MSA and are reported in parentheses. Sample sizes differ across outcomes based on skip patterns in the TUS, differential availability of survey items across survey years, and differential response probabilities.

$* * * ; *$; and $*=$ statistically different from zero at the $1 \% ; 5 \%$; and $10 \%$ confidence level. 
Table 5. Mechanism regression results for immigrant sample: Tobacco Use Supplements 1995-2011

\begin{tabular}{lcc}
\hline & Family income & White collar \\
\hline Sample: women & & \\
\hline Sample proportion & $\$ 74,571$ & 0.3248 \\
\hline Years since migration & $824.1475^{* * *}$ & $0.0030^{* * *}$ \\
& $(58.2182)$ & $(0.0004)$ \\
Percent own-ethnic & 39.4168 & -0.0009 \\
& $(117.2240)$ & $(0.0007)$ \\
Worksite smoking ban index & -141.9518 & -0.0008 \\
& $(598.2046)$ & $(0.0039)$ \\
\hline $\mathrm{N}$ & 19,053 & 20,634 \\
\hline Sample: men & & \\
\hline Sample proportion & $\$ 72,060$ & 0.2817 \\
Years since migration & $870.9475^{* * *}$ & $0.0019^{* * *}$ \\
Percent own-ethnic & $(60.6705)$ & $(0.0003)$ \\
& -60.7927 & $-0.0012^{* *}$ \\
Worksite smoking ban index & $(136.7543)$ & $(0.0006)$ \\
& 51.3275 & 0.0002 \\
N & $(570.4565)$ & $(0.0025)$ \\
\hline
\end{tabular}

Notes: All models estimated with OLS (continuous outcomes) or a linear probability model (binary outcomes), and adjust for individual demographics; state cigarette tax; state smoking ban index for shopping malls, restaurants, and bars; MSA fixed effects; birth country fixed effects; and year fixed effects. Respondents must provide a valid response to at least one of the smoking-related fringe benefits questions (see Table 2A and Table 2B) to be included in the sample.

$* * * ; * *$; and $*=$ statistically different from zero at the $1 \% ; 5 \%$; and $10 \%$ confidence level. 


\section{Data Appendix: Construction of ethnic enclave measures}

We use data from the 1990 and 2000 5\% file of the U.S. Censuses and the 2005 to 2011 ACS to construct our ethnic enclave measures (Ruggles, Alexander et al. 2010). The Census is fielded every ten years to enumerate and collect demographic information on the population. The 1990 and $20005 \%$ files of the Census include approximately 12.5 million and 14 million individuals respectively. The ACS is a large-scale nationally representative survey which is designed to replace the decennial long-form Census. Each ACS provides data for over three million individuals. Both the Census and ACS contain detailed information on country of origin. We limit the sample to the top 50 sending countries in the 1990 Census as sample sizes for particular countries become small outside this range (see Table 1). These countries comprise over $86 \%$ of immigrants in the TUS. We delete observations in which the specific birth country cannot be determined. Examples include Africa (not specified) and Americas (not specified). We construct our proxy for ethnic enclaves as the proportion of individuals from the same birth country in the metropolitan statistical area (MSA) of residence. MSA information is available for roughly $70 \%$ of the TUS, and we exclude respondents with missing MSA information. For example, if a respondent reports that he was born in Ireland and resides in the New York City MSA, we assign him the following value:

$\frac{(\text { population born in Ireland })_{N Y C, t}}{(\text { total population })_{N Y C, t}} * 100$.

Because we do not have full overlap between the TUS data, and the Census and ACS surveys we must impute our enclave measure for non-Census and non-ACS years (i.e., 1995, 1996, 1998, and 1999). Moreover, not all years of our Census (recall that we rely on the 5\% sample) or ACS surveys contain the universe of MSAs in the U.S. Thus, we must impute enclave measures for missing MSAs. Since MSAs are at a much finer geographic level than the state, many of the birth country-by-MSA-by-year cells are small or empty, however. In total, we must impute information for $57 \%$ of our MSA/birth country/year cells. To provide enclave values for all MSAs in all years we utilize prediction equations that regress the percent of residents from each of the 50 included birth countries on birth country, MSA, and year fixed effects, and birth country by state fixed effects using least squares. The adjusted $R^{2}$ from this regression is 0.98 , suggesting that our prediction model has reasonably good fit.

The MSA coding in the TUS (and the CPS more broadly) changed substantially between the 2003 and 2006/07 supplements (specifically, the CPS switched from using the Office of Management and Budget's June 1993 to June 2003 geographic area identification system). We match MSAs between the two classification systems, and achieve a match rate of $95 \%$. More details on our matching procedure are available on request. 


\section{References}

Abbott, M. G. and C. M. Beach (1993). "Immigrant Earnings Differentials and Birth-Year Effects for Men in Canada - Post-War-1972." Canadian Journal of Economics-Revue Canadienne D Economique 26(3): 505-524.

Anson, J. (2004). "The migrant mortality advantage: A 70 month follow-up of the Brussels population." European Journal of Population-Revue Europeenne De Demographie 20(3): 191-218.

Antecol, H. and K. Bedard (2006). "Unhealthy assimilation: Why do immigrants converge to American health status levels?" Demography 43(2): 337-360.

Åslund, O. and P. Fredriksson (2009). "Peer Effects in Welfare Dependence: QuasiExperimental Evidence." Journal of Human Resources 44(3): 798-825.

Bartel, A. P. (1989). "Where Do the New United-States Immigrants Live." Journal of Labor Economics 7(4): 371-391.

Beaman, L. A. (2012). "Social Networks and the Dynamics of Labour Market Outcomes: Evidence from Refugees Resettled in the U.S." The Review of Economic Studies 79(1): 128-161.

Beenstock, M., B. R. Chiswick, et al. (2010). "Testing the immigrant assimilation hypothesis with longitudinal data." Review of Economics of the Household 8(1): 7-27.

Bell, B. and S. Machin (2013). "Immigrant Enclaves and Crime." Journal of Regional Science 53(1): 118-141.

Berman, M., R. Crane, et al. (2013). "Estimating the cost of a smoking employee." Tobacco Control.

Bertrand, M., E. F. P. Luttmer, et al. (2000). "Network effects and welfare cultures." Quarterly Journal of Economics 115(3): 1019-1055.

Biddle, N., S. Kennedy, et al. (2007). "Health assimilation patterns amongst Australian immigrants." Economic Record 83(260): 16-30.

Borjas, G. J. (1982). "The Earnings of Male Hispanic Immigrants in the United-States." Industrial \& Labor Relations Review 35(3): 343-353.

Borjas, G. J. (1985). "Assimilation, Changes in Cohort Quality, and the Earnings of Immigrants." Journal of Labor Economics 3(4): 463-489.

Borjas, G. J. (1995). "Assimilation and Changes in Cohort Quality Revisited - What Happened to Immigrant Earnings in the 1980s." Journal of Labor Economics 13(2): 201-245.

Borjas, G. J. (1998). "To Ghetto or Not to Ghetto: Ethnicity and Residential Segregation." Journal of Urban Economics 44(2): 228-253.

Borjas, G. J. (2005). "The labor-market impact of high-skill immigration." American Economic Review 95(2): 56-60.

Carliner, G. (1980). "Wages, Earnings and Hours of 1st, 2nd, and 3rd Generation American Males." Economic Inquiry 18(1): 87-102.

Centers for Disease Control and Prenvetion (2012). State Tobacco Activities Tracking and Evaluation (STATE) System Database. C. f. D. C. a. Prenvetion.

Centers for Disease Control and Prevention (2008). "Smoking-attributable mortality, years of potential life lost, and productivity losses--United States, 2000-2004." MMWR Morb Mortal Wkly Rep 57(45): 1226-1228.

Chiswick, B. R. (1978). "Effect of Americanization on Earnings of Foreign-Born Men." Journal of Political Economy 86(5): 897-921. 
Chiswick, B. R. and P. W. Miller (2011). "The "Negative" Assimilation of Immigrants: A Special Case." Industrial and Labor Relations Review 64(3): 502-525.

Chiswick, B. R. and P. W. Miller (2012). "Negative and Positive Assimilation, Skill Transferability, and Linguistic Distance." Journal of Human Capital 6(1): 35-55.

Collins, W. J. and R. A. Margo (2000). "Residential segregation and socioeconomic outcomes When did ghettos go bad?" Economics Letters 69(2): 239-+.

Damm, A. P. (2009). "Ethnic Enclaves and Immigrant Labor Market Outcomes: QuasiExperimental Evidence." Journal of Labor Economics 27(2): 281-314.

Edin, P. A., P. Fredriksson, et al. (2003). "Ethnic enclaves and the economic success of immigrants - Evidence from a natural experiment." Quarterly Journal of Economics 118(1): 329-357.

Gruber, J. (1994). "The Incidence of Mandated Maternity Benefits." American Economic Review 84(3): 622-641.

Halpern, S. D., K. M. Madison, et al. (2009). "Patients as Mercenaries? The Ethics of Using Financial Incentives in the War on Unhealthy Behaviors." Circulation-Cardiovascular Quality and Outcomes 2(5): 514-516.

Hao, L. X. and J. J. H. Kim (2009). "Immigration and the American Obesity Epidemic." International Migration Review 43(2): 237-262.

Hull, D. (1979). "Migration, Adaptation, and Illness - Review." Social Science \& Medicine Part a-Medical Sociology A13(1): 25-36.

Institute of Medicine (2010). Secondhand Smoke Exposure and Cardiovascular Effects:Making Sense of the Evidence. Washington, DC, The National Academies Press.

Jensen, G. and M. Morrisey (2001). "Endogenous Fringe Benefits, Compensating Wage Differentials and Older Workers." International Journal of Health Care Finance and Economics 1(3-4): 203-226.

Kaplan, M. S., N. Huguet, et al. (2004). "The, association between length of residence and obesity among Hispanic immigrants." American Journal of Preventive Medicine 27(4): 323-326.

Kennedy, S., J. McDonald, et al. (2006). The Healthy Immigrant Effect and Immigrant Selection: Evidence from Four Countries. Hamilton, ON, McMaster University.

Kondylis, F. (2010). "Conflict displacement and labor market outcomes in post-war Bosnia and Herzegovina." Journal of Development Economics 93(2): 235-248.

Leung, L. A. (2013). "Healthy and Unhealthy Assimilation: Country of Origin and Smoking Behavior among Immigrants." Health Economics.

Levy, H. and R. Feldman (2001). "Does the Incidence of Group Health Insurance Fall on Individual Workers?" International Journal of Health Care Finance and Economics 1(34): 227-247.

Liu, C. Y. (2009). "Ethnic Enclave Residence, Employment, and Commuting of Latino Workers." Journal of Policy Analysis and Management 28(4): 600-625.

Lubotsky, D. (2007). "Chutes or ladders? A longitudinal analysis of immigrant earnings." Journal of Political Economy 115(5): 820-867.

Marmot, M. G., A. M. Adelstein, et al. (1984). "Lessons from the Study of Immigrant Mortality." Lancet 1(8392): 1455-1457.

Miller, R., Jr. (2004). "Estimating the Compensating Differential for Employer-Provided Health Insurance." International Journal of Health Care Finance and Economics 4(1): 27-41. 
Orzechowski and Walker (2012). The Tax Burden on Tobacco: Historical Compilation 2011. The Tax Burden on Tobacco: Historical Compilation Arlington, VA, Orzechowski and Walker,

Palloni, A. and J. D. Morenoff (2001). "Interpreting the paradoxical in the Hispanic paradox Demographic and epidemiologic approaches." Population Health and Aging 954: 140174.

Park, J., D. Myers, et al. (2009). "Immigrant obesity and unhealthy assimilation: Alternative estimates of convergence or divergence, 1995-2005." Social Science \& Medicine 69(11): 1625-1633.

Patel, K. and F. Vella (2012). "Immigrant Networks and Their Implications for Occupational Choice and Wages." Review of Economics and Statistics 95(4): 1249-1277.

Pearson, S. D. and S. R. Lieber (2009). "Financial Penalties For The Unhealthy? Ethical Guidelines For Holding Employees Responsible For Their Health." Health Affairs 28(3): 845-852.

Pew Research Center (2013). A Nation of Immigrants: A Portrait of the 40 Million, Including 11 Million Unauthorized. Washington, DC, Pew Research Center, Pew Hispanic Center.

Roy, A. D. (1951). "Some Thoughts on the Distribution of Earnings." Oxford Economic Papers 3(2): 135-146.

Ruggles, S., J. T. Alexander, et al. (2010). Integrated Public Use Microdata Series: Version 5.0 [Machine-readable database]. U. o. Minnesota. Minneapolis.

Sherman, B. W. and W. D. Lynch (2013). "The Relationship Between Smoking and Health Care, Workers' Compensation, and Productivity Costs for a Large Employer." Journal of Occupational and Environmental Medicine 55(8): 879-884 810.1097/JOM.1090b1013e31829f33129.

Simon, K. I. (2001). "Displaced Workers and Employer-Provided Health Insurance: Evidence of a Wage/Fringe Benefit Tradeoff?" International Journal of Health Care Finance and Economics 1(3-4): 249-271.

The Kaiser Family Foundation and Health Research \& Educational Trust (2012). Kaiser/HRET Survey of Employer-Sponsored Health Benefits, 2012. Santa Monica, CA, The Kaiser Family Foundation and Health Research \& Educational Trust.

Volpp, K. G., A. B. Troxel, et al. (2009). "A randomized, controlled trial of financial incentives for smoking cessation." N Engl J Med 360(7): 699-709.

Warman, C. (2007). "Ethnic enclaves and immigrant earnings growth

Enclaves ethniques et croissance des gains des immigrants." Canadian Journal of Economics/Revue canadienne d'économique 40(2): 401-422.

World Health Organization (2013). Global Health Observatory Data Repository: Tobacco by Country. W. H. Organization. Geneva, Switzerland.

Zhang, X. L., L. Miller, et al. (1999). "Cost of smoking to the Medicare program, 1993." Health Care Financing Review 20(4): 179-196. 